\title{
A comparison of topical acyclovir with steroids in the treatment of herpes zoster keratouveitis
}

\author{
JAMES MCGILL AND CINDY CHAPMAN \\ From the Southampton Eye Hospital, Southampton
}

SUMMARY Topical acyclovir has been compared with topical steroids in a coded controlled trial of the treatment of keratouveitis caused by herpes zoster in 40 patients. Topical acyclovir was significantly superior to topical steroids in terms of treatment duration ( 75 days to 280 days), with no recurrences after the patients were weaned off treatment; there was a $63 \%$ recurrence rate in the steroid group. Corneal epithelial disease resolved significantly quicker in the acyclovir treated group. If recurrences occurred in the steroid group, other parts of the eye not initially affected were also involved. Treatment of such recurrences was more difficult than treatment of the initial attack.

It has been estimated that $50 \%$ of all cases of herpes zoster involvement of the trigeminal nerve develop ocular lesions and, of these, between $40 \%$ and $77 \%$ corneal signs and $50 \%$ to $60 \%$ uveitis. ${ }^{12}$ With an approximate incidence of $0.2 \%$ of herpes zoster in the general population, ${ }^{3}$ of whom between $7 \%$ and $20 \%$ will develop ocular lesions, ocular herpes zoster is thus a frequent cause of ocular damage, and so an effective treatment is required.

Topical steroids have been used for some time to control the ocular effects of herpes zoster infection, but the treatment has side effects. Treatment is frequently prolonged over many months, and the ocular signs of herpes zoster reappear either during withdrawal of steroids or after they have been stopped. Despite intensive topical steroid treatment severe ocular damage and visual loss may result, and once treatment has been withdrawn vision may gradually be lost owing to the development of corneal scars. Current treatment of ocular herpes zoster infection is unsatisfactory, and an alternative, more effective, treatment is required.

Recent advances in the development of antiviral drugs have shown that the new synthetic nucleoside, acycloguanosine (acyclovir, Zovirax) has potential activity against the herpes zoster virus. ${ }^{4}$ In the immune competent host with herpes zoster infection, acyclovir topically applied appears to control the ocular signs, ${ }^{5}$ and given systemically it has a beneficial

Correspondence to $\mathrm{Mr}$ J. McGill, FRCS, Southampton Eye Hospital, Wilton Avenue, Southampton SO9 4XW. effect on the rash, reducing cropping and its duration. $^{\leftrightarrow \rightarrow}$ No other antiviral has been definitely shown to benefit either the rash or the ocular lesions of herpes zoster.

The alternative antiviral therapies tried for herpes zoster ophthalmicus include systemic interferon, which was found to be without effect, ${ }^{10}$ but this may have been due to the low dose of interferon used in a comparatively short-treatment regimen of 5-10 days and the lack of ocular penetration. Short-treatment regimens have no effect on ocular lesions; systemic acyclovir given for 5 days, while suppressing the cutaneous rash, had no effect on ocular lesions. ${ }^{9}$ Other antivirals such as systemic adenine arabinoside have also been without effect. ${ }^{11}$

The question arises whether topical acyclovir or steroids are the more effective in the treatment of acute herpes zoster ophthalmicus. A double-blind clinical trial was set up comparing these 2 drugs.

\section{Material and methods}

SELECTION OF PATIENTS

Forty immune competent patients with active herpes zoster ocular involvement but no evidence of malignancy were entered into the trial. The diagnosis was made on clinical grounds, backed up where possible by viral isolation when skin vesicles were still present. We aimed to exclude those who were monocular or who had less than $6 / 24$ vision in the other eye, who were aged under 18 or of child-bearing potential, or who had other ocular disease present, 
and those who had already received treatment for their ocular condition.

Patients were randomly allocated on a doublemasked basis to either oc. acyclovir 5 times a day or oc. Betnesol (betamethasone) 5 times a day. Cycloplegics were added if necessary, if uveitis was present.

\section{INITIAL INVESTIGATIONS}

Note was taken of the patient's age, duration of prodromal symptoms, rash and when resolved, treatment for the rash, and any nasociliary involvement. Details of the patient's general health, concurrent drugs, and whether there had been a history of previous herpes zoster infection were recorded.

The type of ocular symptom - pain, photophobia, grittiness, and lacrimation-were assessed on a $0-3+$ basis. The following signs of eye involvement were recorded, with a severity scale as indicated:

Visual acuity; presence of lid involvement, with any deformity of the lid; state of the rash assessed in terms of macules, vesicles, or crusts; degree of scleral injection (0-3+); area of any nodular episcleritis or scleritis $(0-4+)$; conjunctiva examined for bulbar hyperaemia, papillae, or follicles in the palpebral areas, with or without thickening, scarring, or keratinisation; corneal anaesthesia, assessed with a cotton-wool wick; corneal epithelial appearance, and fluorescein staining $(0-3+)$ to demonstrate active herpes zoster type of corneal epithelial involvement, either as a superficial punctate keratitis associated with epithelial vesicles, or herpes zoster dendritiform

Table 1 Distribution of patients into the 2 treatment groups

\begin{tabular}{|c|c|c|}
\hline & Acyclovir group & Steroid group \\
\hline Number & 17 & 19 \\
\hline Median age (years) & 71 & 71 \\
\hline Sex & $12 \mathrm{~F} \quad 5 \mathrm{M}$ & $12 \mathrm{~F} \quad 7 \mathrm{M}$ \\
\hline $\begin{array}{l}\text { Prodromal rash symptoms } \\
\text { (median days) }\end{array}$ & 5 & 5 \\
\hline $\begin{array}{l}\text { Percentage with rash healed } \\
\text { on entry }\end{array}$ & 53 & 32 \\
\hline $\begin{array}{l}\text { Median days rash present } \\
\text { before presentation }\end{array}$ & 5 & 5 \\
\hline $\begin{array}{l}\text { Prodromal eye symptoms on } \\
\text { entry (median days) }\end{array}$ & 2 & 2 \\
\hline Median symptom scores: & & \\
\hline stromal lesions severity & $1 \cdot 0$ & $1 \cdot 5$ \\
\hline area & $1 \cdot 0$ & $1 \cdot 5$ \\
\hline severity & $1 \cdot 0$ & $1 \cdot 5$ \\
\hline scleritis & $1 \cdot 0$ & $1 \cdot 5$ \\
\hline area & $2 \cdot 0$ & $2 \cdot 0$ \\
\hline $\begin{array}{l}\text { Mean follow-up after } \\
\text { treatment finally stopped } \\
\text { (months) }\end{array}$ & $\begin{array}{l}19 \\
\text { (range 3-28) }\end{array}$ & $\begin{array}{l}13^{*} \\
\text { (range } 0-22 \text { ) }\end{array}$ \\
\hline
\end{tabular}

* Note longer post-treatment follow-up in acyclovir group due to more prolonged treatment in steroid group, though entry into trial was at the same time in each group. ulceration $^{12}$ (this was differentiated from central superficial punctate erosions, with no epithelial vesicles, found in the presence of corneal anaesthesia); degree of any corneal lipid deposition or scarring (0-4+: $0=$ none, $1=$ very mild, $2=$ moderate, $3=$ severe, $4=$ dense); active stromal infiltration and oedema, either as a nummular keratitis or a disciform keratitis $(0-3+: 0=$ none, $1=$ mild, $2=$ moderate, $3=$ severe), together with the type and depth of vascularisation); uveitis ( $0=$ none; $1-2+=$ mild, flare or cells, or keratic precipitates (KP) at one site, $3+=$ severe, flare and cells, KP generalised); state of the iris, whether the pupil was active, and whether there was any segmental necrosis; clarity of the ocular media, including the lens; fundal appearance; any extraocular muscular paresis.

Photographic records were taken, as well as viral cultures of any active lid or corneal ulcer.

At each follow-up visit the above details were recorded on a prepared proforma sheet.

TREATMENT AND FOLLOW-UP

During the course of active treatment each patient was seen initially every 2 to 3 days, then on a weekly to 2-weekly basis.

Patients had full topical treatment until the active ocular involvement ceased, and were then slowly weaned off treatment over the next 4 to 6 weeks. Recurrences were analysed into the following groups: group I, reappearance of the signs while the patient was being weaned off treatment; group II, the signs reappeared within 3 weeks of withdrawal; group III, the signs reappeared after treatment had been withdrawn for at least 3 weeks. Once treatment had ceased, the patient was seen a week later and then if necessary on a weekly basis until it was certain there were no signs of any recurrence. Thereafter the patients were checked at 3-and 6-month intervals.

If at any time the signs of disease increased on 3 consecutive visits, the code was broken, and for those patients on steroids the steroid dose was increased and for those on acyclovir steroids were added.

If there was a recurrence of either type of ocular involvement, the original treatment was restarted, if it had been successful, and then the patient was slowly weaned off it.

\section{Results}

There was an even distribution of patients into the 2 treatment groups in terms of age, duration of prodromal symptoms of both the rash and eye symptoms, time of the rash being present, and the number, size, and area of each individual aspect of the ocular disease affecting the cornea, sclera, or uveal tract (Table 1). 
Table 2 The outcome of treatment with either topical acyclovir or topical steroids betamethasone (Betnesol) 5 times a day on acute herpes zoster ocular involvement. The initial treatment period was for the first attack. If there was a recurrence, treatment was restarted, and weaned off as the eye settled. Total treatment duration was the period of treatment for the initial and recurrent attacks (mean)

\begin{tabular}{|c|c|c|}
\hline & Acyclovir group & Steroid group \\
\hline $\begin{array}{l}\text { Number } \\
\text { Number healed } \\
\text { Initial treatment duration } \\
\text { Number with disease } \\
\text { recurrence } \\
\text { Total duration of treatment }\end{array}$ & $\begin{array}{l}17 \\
16 \\
76 \text { days }{ }^{\dagger} \\
0 \\
76 \text { days* } \\
\text { (range } 40-147 \\
\text { days) }\end{array}$ & $\begin{array}{l}19 \\
18 \\
96 \cdot 9 \text { days }{ }^{\dagger} \\
12 \\
280 \text { days* } \\
\text { (range } 38-750 \\
\text { days) }\end{array}$ \\
\hline
\end{tabular}

*Statistically significant difference $(<0 \cdot 001)$.

$\dagger$ No statistical difference $(p>0 \cdot 1)$.

Of the 20 patients who received topical acyclovir one was withdrawn from the trial because the protocol was not adhered to, with an extra drug being added to the regimen, one failed to return for followup, and one died of cerebrovascular disease. Of the remaining 17 acyclovir successfully controlled the ocular signs in 16. One patient had an increase in corneal oedema and infiltration on 3 successive visits and so was withdrawn from the trial, the code was broken, and topical steroids were added. The median duration of treatment of the other 16 patients was 76 days (Table 2), with individual signs resolving quicker (Table 3). Once treatment was stopped, there was no reappearance of the ocular signs, with a maximum follow-up of 28 months and a minimum of 9 (average 19 months).

In the steroid treated group of 20 patients one was withdrawn, as it was subsequently discovered that she had malignant disease and had had a previous attack of ocular herpes zoster. Eighteen of the remaining 19 patients responded favourably to treatment, but one patient required an increase in his topical steroid regimen (up to dexamethasone $0.1 \%$ drops hourly and betamethasone ointment at night) to suppress the ocular signs. The median duration of initial treatment for the group was similar to that of the acyclovir group at 96.9 days. Once treatment had been stopped or the patient was being weaned off it, 12 out of 19 patients had a recurrence of keratouveitis (Table 2), and at the time of analysis treatment was required for up to 750 days, making the median duration of treatment required for the whole group 280 days, which was significantly longer than for the acyclovir group (Table 2). The final analysis was carried out 10 months after the onset of the last patient's treatment had been started, when 7 of the patients were still receiving topical steroids for recurrent disease, so that the total mean treatment period is artificially low. The duration of treatment prior to stopping the steroids is given in Table 4.

The corneal lesions affecting the epithelium (superficial punctate keratitis or ulceration) resolved significantly quicker in the acyclovir treated group than in the steroid group ( $p<0.001$; Table 3$)$, but there was no difference in the stromal, uveal, or scleral response between the 2 groups. There was no difference between the 2 groups in the onset of the prodromal symptoms, and, apart from epithelial disease, in neither treatment group was there an increased incidence of new signs developing after treatment had started. Two patients in the steroid treated group had a progression of their epithelial disease while on treatment, with punctate erosions progressing into larger lesions (i.e., dendritiform ulcers). In other words, once full treatment had started, uveitis or stromal disease did not appear in either group in greater frequency. Once treatment was being tailed off in the steroid group, 7 patients developed disease of areas (i.e., corneal or uveal tract) not initially involved. Treatment of these recurrences was more prolonged and difficult than of the initial attack.

Three of these patients in the steroid group ran into problems. Two, as a result of corneal infiltration and an anaesthetic cornea, developed chronic corneal

Table 3 Distribution and median duration of individual signs in the 2 groups (in days)

\begin{tabular}{|c|c|c|c|c|}
\hline \multirow[t]{2}{*}{ Type } & \multicolumn{2}{|l|}{ Acyclovir } & \multicolumn{2}{|l|}{ Steroid } \\
\hline & Duration & Number & Duration & Number \\
\hline Acute epithelial lesion & $\begin{array}{l}4^{*} \\
\text { (range 1-9) }\end{array}$ & $\begin{array}{l}\text { Ulcer: } 6 \\
\text { SPE: } 4\end{array}$ & $\begin{array}{l}13^{*} \\
\text { (range } 7-23 \text { ) }\end{array}$ & $\begin{array}{l}\text { Ulcer: } 9 \\
\text { SPE: } 6\end{array}$ \\
\hline Stromal lesion & $\begin{array}{l}20 \\
\text { (range 4-32) }\end{array}$ & $\begin{array}{l}\text { Nummular: } 8 \\
\text { Disciform: } 4\end{array}$ & $\begin{array}{l}21 \\
\text { (range 5-92) }\end{array}$ & $\begin{array}{l}\text { Nummular: } 8 \\
\text { Disciform: } 1\end{array}$ \\
\hline Uveitis & 21 & 16 & $\begin{array}{l}18 \\
\text { (range 3-196) }\end{array}$ & 16 \\
\hline Scleritis & $\begin{array}{l}42 \\
\text { (range } 7-105 \text { ) }\end{array}$ & 8 & $\begin{array}{l}15 \\
\text { (range 5-364) }\end{array}$ & 9 \\
\hline
\end{tabular}

${ }^{*} \mathrm{p}<0.001$ (Mann-Whitney U test, 2-tailed). SPE=superficial punctate erosions. 
Table 4 Average duration of treatment of the initial attack of those steroid-treated patients with recurrent disease

\begin{tabular}{lll}
\hline & Number & $\begin{array}{l}\text { Average days } \\
\text { of initial } \\
\text { treatment }\end{array}$ \\
\hline $\begin{array}{l}\text { Group I: Recurred while on } \\
\text { treatment }\end{array}$ & 0 & 0 \\
$\begin{array}{l}\text { Group II: Recurred after treatment } \\
\text { stopped less than 3 weeks before }\end{array}$ & 8 & 95 \\
$\begin{array}{l}\text { Group III: Recurred after treatment } \\
\text { stopped 3 weeks or more before }\end{array}$ & 4 & 53 \\
\hline
\end{tabular}

ulceration, which necessitated a tarrsorraphy. A third patient had recurrent uveitis with secondary glaucoma, which was initially suppressed by increasing the topical steroids, but then a steroidinduced glaucoma supervened, which complicated therapy. Treatment was changed to steroids with low ocular hypertensive effect, to no avail, and eventually the patient required drainage surgery to control the intraocular pressure.

There was no difference in the incidence of secondary glaucoma between the 2 groups. Three patients in the acyclovir group and 6 in the steroid group developed anaesthetic corneas, and some required long-term topical lubrication to prevent recurrent corneal erosions. One patient in the steroid-treated group had a significant fall in vision (from 6/9 to $<6 / 60$ ) as a result of stromal infiltration and scarring. Otherwise there was no significant difference in the final visual acuity between the groups.

\section{Discussion}

The prominent feature of this trial has been the resolution of the ocular signs of herpes zoster infection in the acyclovir treated group without any recurrences once treatment was tapered off and stopped. In the steroid-treated group the average duration of treatment was significantly longer.

Of interest was the quicker resolution of the corneal signs of ulceration in the acyclovir group. It has previously been reported that herpes zoster virus can be cultured from acute herpes zoster corneal ulcers, ${ }^{13}$ and so it would be expected that lesions in the acyclovir group would resolve quicker, for steroids have no antiviral effect.

The mechanism is unknown of the stromal and uveal tract complications of herpes zoster ophthalmicus. In patients developing disseminated herpes zoster there is a possible abnormality of immunity, with a late rise in interferon and a delayed development of virus-specific complement-fixing antibody, but, when dissemination does not occur, interferon levels rise earlier as viral isolation rates in vesicular fluid decline. ${ }^{14} 15$ This suggests that the initial event is viral invasion, which subsequently stimulates an immune response. This is supported by the observation that systemic acyclovir ${ }^{7 \rightarrow}$ or interferon $^{16}$ arrests and prevents further skin or visceral involvement. In the skin the initial lesion is a vasculitis. Similar lesions occur in the eye. In cases with iris atrophy there is occlusion of iris vessels. ${ }^{17}$ In ocular and orbital structures a vasculitis occurs ${ }^{18} 19$ and in cerebral involvement a granulomatous angiitis. ${ }^{2021}$ So far no one has reported culturing herpes zoster virus from the corneal stroma or detecting viral particles in it (by the electron microscope), but this may be due to the difficulty of detecting a few viral particles in a comparatively large corneal area by means of fine sections covering only a limited zone at a time. That viral particles are present in the cornea has been suggested by their being cultured from the acute epithelial lesions and by the presence of viral particles in the corneal epithelium of a patient with disciform keratitis treated with topical steroids, occurring 8 months after the onset of herpes zoster ophthalmicus. ${ }^{22}$ Viral particles have also been detected in the retina of a patient with retinitis following herpes zoster infection. ${ }^{19}$ Thus most of the ocular lesions could be attributed to local viral invasion. If acyclovir suppressed local viral replication, it would prevent viral particles invading the tissues further. Steroids, although suppressing the inflammatory signs, enhance viral replication and so prolong the disease process.

The results reported here support the theory that if topical steroids are used in the treatment of herpes zoster ophthalmicus, treatment should be continued on low-dose maintenance therapy for some considerable time after the resolution of the signs in order to prevent reactivation of the disease.

This trial may merely be demonstrating the deleterious effects of steroids on this condition, and the apparently beneficial effect of acyclovir may have been a placebo effect, as no placebo controls were included. That acyclovir is actively effective is suggested by the observation that patients treated with placebo (as part of the systemic placebocontrolled trial of acyclovir ${ }^{9}$ ) suffered a progression of their ocular signs of herpes zoster, which halted when topical acyclovir was started. Prospective placebo-controlled trials of topical acyclovir in herpes zoster keratouveitis are required. But it is ethically difficult to justify treating with a placebo a patient with a severe, painful keratouveitis and an opaque, oedematous cornea, so such trials may not be possible.

We are grateful to Mr C. B. Walker, Mr A. R. Elkington, and Mr I. H. Chisholm for referring patients to this study, and to Dr P. Reese for help with the statistics. 


\section{References}

1 Marsh RJ. Ophthalmic herpes zoster. Br J Hosp Med 1976; 15: 609-18.

2 Womack LW, Liesegang TJ. Complications of herpes zoster ophthalmicus. Arch Ophthalmol 1983; 101: 42-5.

3 Vachtenheim J, Grossman J. Herpes zoster and steroid therapy. Br Med J 1963; ii: 622 .

4 Biron KK, Elion GB. Sensitivity of varicella zoster virus in vitro to acyclovir. 19th Interscience Conference on Antimicrobial Agents and Chemotherapy. Boston, 1979: 249.

5 McGill J. Topical acyclovir in herpes zoster ocular involvement. Br J Ophthalmol 1981; 65: 542-5.

6 McGill J, James C, Hiscott P, Worstmann T, Larkin M. The use of acyclovir in the treatment of herpes zoster ocular infections. In: Sundmacher R, ed. Herpetische augenerkrankungen. Munich: Bergmann, 1981: 461-4.

7 Peterslund NA, Seyer-Hansen K, Ipsen J, Esmann V, Schonheyder H, Juhl H. Acyclovir in herpes zoster. Lancet 1981; ii: $827-30$.

8 Bean B, Braun C, Balfour HH. Acyclovir therapy for acute herpes zoster. Lancet 1982; ii: 118-21.

9 McGill J, McKenzie D, Fall C, McKendrick DM. Intravenous acyclovir in acute herpes zoster infection. $J$ Infection in press.

10 Sundmacher R, Neumann-Haefelin D, Cantell K. Trials with interferon in ophthalmic zoster. In: Sundmacher R, ed. Herpetische Augenerkrankungen. Munich: Bergmann, 1981: 465-7.

11 Marsh RJ. Laird R, Atkinson A, Steel A McD, Jones BR. A controlled trial of intravenous therapy with adenine arabinoside (Ara-A) in ophthalmic zoster. In: Sundmacher R, ed. Herpetische Augenerkrankungen. Munich: Bergmann, 1981: 449-54.

12 Marsh RJ, Fraunfelder F, McGill JI. Herpetic corneal epithelial disease. Arch Ophthalmol 1976; 94: 1899-1902.

13 Pavan-Langston D, McCulley JP. Herpes zoster dendritic keratitis. Arch Ophthalmol 1973; 89: 25 .

14 Stevens DA, Merigan TC. Interferon, antibody, and other host factors in herpes zoster. J Clin Invest 1972; 51: 1170-8.

15 Larkin M, Ogilvie MM, McGill JI. Effect of low dose acyclovir $(5 \mathrm{mg} / \mathrm{kg})$ on virus shedding, interferon and humoral immunity in herpes zoster. J Antimicrob Chemother in press.

16 Merigan TC, Rand KH, Pollard RB, Abdallah PS, Jordan GW, Fried RP. Human Leukocyte interferon for the treatment of herpes zoster in patients with cancer. N Engl J Med 1978; 298: 981-7.

17 Marsh RJ, Easty DL, Jones BR. Herpes zoster ophthalmicus. Am J Ophthalmol 1974; 78: 255-61.

18 Naumann G, Gass JDM, Font RL. Histopathology of herpes zoster ophthalmicus. Am J Ophthalmol 1968; 65: 533-41.

19 Schwartz JN, Cashwell F, Hawkins HK, Klintworth GK. Necrotizing retinopathy with herpes zoster ophthalmicus. Arch Pathol Lab Med 1976; 100: 386-91.

20 Gilbert GJ. Herpes zoster ophthalmicus and delayed contralateral hemiparesis. JAMA 1974; 229: 302-4.

21 Linnemann CC Jr, Alvira MM. Pathogenesis of varicella zoster angiitis in the CNS. Arch Neurol 1980; 37: 239-40.

22 Hayashi K, Uchida Y, Oshima M. Fluorescent antibody study of herpes zoster keratitis. Am J Ophthalmol 1973; 75: 795-8. 